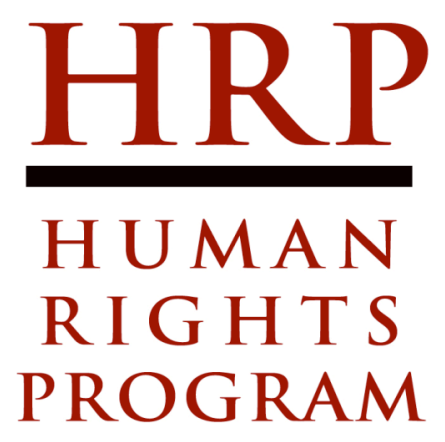

Human Rights Program at Harvard Law School Working Paper July 2007

The Recognition of Muslim Personal Laws in South Africa: Implications for Women's Human Rights

\title{
RASHIDA MANJOO
}

\author{
Human Rights Program at Harvard Law School \\ 1563 Massachusetts Avenue - Pound Hall 401 \\ Cambridge, MA 02138
}

No part of this paper may be reproduced in any form without permission of the author. 


\title{
The Recognition of Muslim Personal Laws in South Africa: Implications for Women's Human Rights
}

\author{
C)Rashida Manjoo \\ Visiting Fellow, September 2006-December 2007 \\ Human Rights Program at Harvard Law School \\ Former Commissioner of South Africa's Commission on Gender Equality \\ Law, Race, and Gender Research Unit - University of Cape Town \\ Email: rmanjoo@law.harvard.edu
}

Rashida Manjoo is an Advocate of the High Court of South Africa and a former commissioner of the Commission on Gender Equality (CGE), a constitutional body mandated to oversee the promotion and protection of gender equality. Prior to being appointed to the CGE she was involved in social context training for judges and lawyers, where she has designed both content and methodology during her time at the Law, Race, and Gender Research Unit-University of Cape Town and at the University of Natal, Durban.

The Human Rights Program (HRP) seeks to give impetus and direction to international human rights work at Harvard Law School. Established in 1984, HRP works to educate students who will be among the leaders of the human rights movement, and fosters progress within the movement through its scholarship, engagement, criticism and suggestions. For more information on HRP, visit www.law.harvard.edu/programs/hrp. 


\title{
THE RECOGNITION OF MUSLIM PERSONAL LAWS IN SOUTH AFRICA: IMPLICATIONS FOR WOMEN'S HUMAN RIGHTS
}

\author{
Editor: Rashida Manjoo
}

\section{1) Introduction}

Bringing personal status laws into conformity with international and constitutional equal rights provisions is an imperative for the protection of women's human rights. Multicultural secular democracies face a challenge in effectively and meaningfully guaranteeing the right to equality and the right to religion and culture. Currently, Muslim marriages are not legally recognized in South Africa. Nearly 1.5 million of South Africa's citizens are Muslims, yet their marriages do not enjoy legal status. Some seek out the civil law system, but the rest are without formal legislative redress when problems arise within a marriage. This creates problems for parties in Muslim marriages generally, but for women in particular, especially in the family law arena.

This report identifies potential constitutional violations that may emerge in the law reform efforts that are currently taking place in South Africa. It explores amongst other issues, the tensions between women's equality rights and religious rights, codification of religious personal status laws versus recognition of religious marriages, achieving equal access to justice for all women, and also tensions arising between individual equality rights and group equality rights.

\footnotetext{
* This report reflects research undertaken by students registered in the Clinical Advocacy Course at the Human Rights Program (HRP), Harvard Law School. HRP offers course work and fosters the participation of students in human rights activities. Amongst other activities, HRP also develops and supervises student clinical projects. One of the projects embarked on by students in 2005/6 was that of "[T] Re Recognition of Muslim Personal Laws in South Africa: Implications for Women's Human Rights”. Students involved in the project included: Mujon Baghai, Nazia Izuddin, Elodie Moser, Yvonne Osirim, Pranvera Recica and Erica Westernberg. The project was conceptualised and supervised by Rashida Manjoo (Visiting Fellow, Human Rights Program/ Research Assoc, Law Faculty- University of Cape Town, South Africa). This report is based on work undertaken over two semesters by law students and also further work undertaken by the editor. It reflects a narrow and more legalistic approach to the issue of recognition of religious marriages in South Africa, as opposed to a sociological or anthropological approach.
} 
South Africa is in the process of considering separate legislation that will recognize Muslim marriages. In July 2003, the South African Law Reform Commission (SALRC) submitted a report to the Minister of Justice along with proposed draft legislation called the Muslim Marriages Act (hereinafter referred to as the SALRC bill) which would recognize Muslim marriages. ${ }^{1}$ The proposed bill addresses the registration of Muslim marriages, the dissolution of such marriages, custody of and access to minor children, and the issue of maintenance (both spousal and child support). Provision is also made for the regulation of polygynous marriages. According to the SALRC, adoption of the draft bill would go a long way in creating legal certainty regarding Muslim marriages; it would give effect to Muslim values; and it would afford better protection to women in those marriages, in accordance with both Islamic and South African constitutional tenets. The SALRC draft bill codifies elements of Muslim Personal Laws, by outlining rules for a variety of marital situations. The provisions in the SALRC bill are similar to provisions on Muslim Personal Laws as codified or applied in some countries including India, Nigeria, Malaysia, Bangladesh, Uganda, Tanzania, Pakistan and Sri Lanka. Though most of these countries are multicultural, they succumb to different models of multiculturalism. Each of these models demonstrates a different approach to Muslim Personal Laws. Section three below will discuss Ayelet Shachar's models of multiculturalism and also some consequences that have arisen in a few Asian and African countries which have adopted Muslim Personal Laws.

As a consequence of receiving numerous concerns relating to the SALRC Bill, which revolved around both constitutionality issues generally and women's right to equality in particular, the Parliamentary Office of the South African Commission for Gender Equality (CGE) drafted an alternative draft bill in October 2005. This Bill, called the Recognition of Religious Marriages Bill (hereinafter referred to as the CGE bill), was produced with the assistance of the office of the State Law Advisor, and was in fulfillment of the CGE's constitutional mandate. ${ }^{2}$ This is a secular bill, of general application, that provides for the recognition of all religious marriages and avoids issues of codification of specific religious tenets, so as to comply with both international and constitutional law imperatives. It also addresses the lacuna that exists with respect to the non-recognition of other religious marriages. 
The CGE Bill was discussed with the SALRC and then handed over to the relevant executive structures. The hope was that broad public consultations would be held by them, particularly by the Gender Directorate of the Department of Justice. But neither the Ministry of Justice nor the Ministry of Home Affairs has acceded to numerous requests for a meeting with the CGE, nor have they undertaken any public consultations on the CGE Bill. The most recent development has been the discussion of potential litigation, to challenge the unconstitutionality of non-recognition of marriages conducted under Muslim laws. ${ }^{3}$

In assessing the best approach to the problem of non-recognition of religious marriages, the South African constitution must be interpreted in its historical context, i.e. by focusing on fundamentally reversing the effects of racial and gender discrimination that existed under apartheid. The constitutional mandate is transformative justice and hence the goal is substantive equality, not just formal equality. ${ }^{4}$ The centrality of equality is reflected in the fact that the Constitution sets forth human dignity, equality, and non-sexism as foundational values. ${ }^{5}$ South Africa's courts have stressed that this history of discrimination and the push to remedy the real-world impact of such wrongs must inform any interpretation of the Constitution, especially the provisions on equality. ${ }^{6}$ Taking all these factors into account, this report attempts to set out the applicable international and constitutional law obligations; the relevant domestic jurisprudence that is of persuasive value; and, finally examines a few sections of both draft Bills. The relevant sections that are examined, relate broadly to the achievement of the rights to substantive gender equality, freedom of religion and access to justice.

\section{2) Methodology}

Students registered in the Clinical Advocacy Course in the Human Rights Program, Harvard Law School in 2005/6, conducted desktop research on the constitutional validity, impact, and consequences of the abovementioned bills. Research also included a comparative analysis, seeking to identify practices and legislative models in select countries in Africa, Asia, Europe and North America. The one week field work undertaken in October 2005 included: the presentation of the research at a workshop hosted by the CGE in Cape Town; interviews with 
academics, community members, and government officials; and participation in a seminar with staff of the CGE. For the purposes of the latter seminar, the students engaged in an indepth discussion on comparisons that reflected their analysis of the differences and also the implications of both the Bills. ${ }^{\dagger}$ The findings and debates emanating from the desktop research and the field-work are reflected in this report. This report will be shared with the CGE and with relevant civil society organizations. It is hoped that it will be used for the purposes of advocacy at both the legislative and litigation levels, in respect of the promulgation of constitutionally sound legislation which recognizes all religious marriages, without violating women's human rights. This report uses the term Muslim Personal Laws to refer to personal status laws emanating from the tenets of Islamic religious sources.

\section{3) Models of multiculturalism}

\subsection{General}

This section largely draws on the work of Ayelet Shachar, who distinguishes between two different models of multiculturalism: the religious particularist model and the secular absolutist model. The 'religious particularist model' is a governance model in which different religious communities are vested with legal power over their members' personal statuses. ${ }^{7}$ This model addresses the problem of respecting cultural differences by granting religious communities the authority to follow their own traditions in the family law arena. Communities are vested with legal power over matters of personal status and property relations, and the state does not regulate citizens' marriage and divorce affairs. ${ }^{8}$

The second model, the 'secular absolutist model' is a system in which the state retains authority over family law matters and all citizens are subject to a uniform secular family law. Under the secular absolutist model, the state defines legally what constitutes the family and regulates its creation and dissolution. A uniform secular state law is imposed upon all citizens in family law matters, regardless of those citizens' group affiliation(s). Religious officials have no prescribed role in defining or celebrating marriages. ${ }^{9}$ In its ideal form, the

\footnotetext{
${ }^{\dagger}$ The speakers and focus of each presentation at the workshop included: Elodie Moser - "Multiculturalism and Legal Systems - Models at Work"; Nazia Yusuf Izuddin - "A Comparative Analysis of Muslim Personal Law in Africa and Asia: Indicators for the South African Bill"; and Erica Westenberg - "Constitutional Analysis of Proposed Muslim Marriages Act”. Mujon Baghai and Yvonne Osirim contributed to the desk-top research which informed sections of the presentations.
} 
secular absolutist model denies legal recognition for a marriage or divorce performed by a representative of a religious family law tradition. It also refuses to acknowledge the possible distributive aspect of religious family law traditions. In other words, the state does not allocate any legal authority to the groups over issues of status or property relations, preserving for itself the ultimate regulatory power over the citizenry in matters of marriage and divorce. In theory, the key apparent advantage of the secularist absolutist model is that it creates a legal regime in which the state has a hold over all ministers, which then avoids the claim that “... the state only supports the practices of the majority [population] in the family law arena." ${ }^{10}$ Hence, all forms of religious marriage and divorce proceedings, whether Christian, Muslim, Jewish, Hindu, etc, have no legal validity under state law. In practice, however, the allocation of legal authority set by the secular absolutist model clearly does not advance the preservation of groups through the accommodation of their diversity: rather it falls short of respecting and addressing family laws and traditions, other than those that exist in the dominant religious, social and legal systems. As Shachar suggests, “... [t]he secular absolutist model is based on the presumption that religious practices are relegated to the "private" realm."11

Shachar argues that one can distinguish the 'secular absolutist model' of civil law countries such as France, Germany, and the Netherlands, in which there is strict separation of church and state, ${ }^{12}$ and the 'modified absolutist system' employed in Australia, Britain, Canada, and the United States, which permits some formal recognition of religious traditions, such as by authorizing religious officials to solemnize marriages. ${ }^{13}$ In the latter model, the state still maintains its decisive authoritative power to regulate citizens' marriage and divorce affairs, but state family law codes have been rewritten so as to sanction greater cultural diversity. For instance, civil authorities may invest religious officials with parallel authority to formalize marriages. ${ }^{14}$ Shachar points out that “... [t]his [modified absolutist] model is important because it provides formal recognition of certain aspects of minority communities' family law traditions." "15 She also shows that "... [a]t the same time, it created a legal route for secular authorities to limit the exploitative power used by religious spouses to gain excessive rights in exchange for religious divorce decrees."16 However, while this legal arrangement may well resolve some individual cases of oppression, it does not create any encouragement for religious communities to reconsider their internal norms. She states ... "[T]his model may 
just incite more reactive culturalist response - even well-meaning modifications by the state still have the effect of preserving a basic imbalance." ${ }^{17}$ Though secular countries can follow this route to control gender injustice and other forms of religious control in the secular sphere, the modified absolutist model is unlikely to prevent the violation of women's human rights.

While the concepts of multiculturalism and legal pluralism have drawn significant scholarly attention and debate in the past decade, large scale legal pluralism in the area of family law has not taken root in western industrialized countries. In the United States we see traces of legal pluralism, where Native Americans retain powers of self-government that extends to family law. In Australia and New Zealand, Aboriginal and Maori customary law receive some recognition, but courts do not apply or enforce this customary law directly. In common law countries, some religious clergy have legal authority to formalize marriages, provided that the parties obtain a marriage license from the state. With these small exceptions, western industrialized countries largely maintain unified family law systems, and persons of all religious, cultural, and ethnic backgrounds are subject to the same family law rules and institutions. In contrast, a pluralist system can be characterized as one that maintains the autonomy and sovereignty of different minority cultures. ${ }^{18}$ Schachar points out both the benefits and the risks inherent in pluralist systems. She argues that pluralist systems may put at risk the equality rights of vulnerable group members, while uniform systems might do a better job at protecting citizenship rights and ensuring equal treatment. On the other hand, such pluralist systems may also deny the importance of particular cultural or religious norms, and discriminate against minority groups, whose traditions are distinct from those embedded within the dominant culture. In Schachar's view, one solution to achieving the protection and promotion of both individual and group rights is to have a joint governance system between the state and the cultural group. ${ }^{19}$

\section{2) Comparing Models from Asia and Africa}

This section sets out a brief picture of the challenges and consequences of the adoption of Muslim Personal Laws in a few Asian and African countries. An unavoidable tension in codifying Muslim Personal Laws in different contexts is whether to adopt a monolithic or a pluralistic system. This is partly due to the reality that there is usually neither a homogenous Muslim community nor a single interpretation of religious laws in that context. Furthermore, 
the issue of the public status and role of religion is also a contested one in many countries. For example, India, Nigeria, Kenya, Tanzania and Sri Lanka are secular nations to the extent that the Constitution does not recognize a state religion. All of these countries, however, have recognized Muslim citizens to be governed by their personal laws relating to marriage, divorce, maintenance (spousal and child support), custody and guardianship, and have hence codified Muslim Personal Laws. On the other hand, the main sources of law in Pakistan, Bangladesh, Malaysia and Zanzibar are Muslim Laws, with Pakistan and Bangladesh declaring Islamic Law as the state religion in their constitutions.

Despite the difference in constitutional status granted to religious law there are some parallels in the effects of application of such laws in these countries. The substance of Muslim Personal Laws and also the interpretations thereof have given rise to contestation in many countries, particularly by women's rights activists. Some questions of concern include: what constitutes a valid marriage under Muslim Laws; what are valid religious precepts; what are the rules of spousal maintenance and child support; what are the rights of spouses in a marriage etc. Though these questions involve the basic tenets of Muslim Personal Laws and give the impression of certainty as to response and broad consensus on the issues, they have also evolved into controversies concerning which religious school of interpretation prevails. The criticism is that giving legitimacy to one school of interpretation excludes the beliefs and rights of people who adhere to a different school, and this exclusion amounts to discrimination on the basis of religious belief. In the South African scenario, the SALRC bill is vulnerable to these criticisms, as it gives priority to one school of interpretation over the other. As Shafi and Hanafi schools are the dominant schools of interpretation in South Africa, the legislation tends to exclude Shia practices and certain practices that are particular to the Maliki and Hanbali schools of interpretation. In the interviews conducted, some people argued that in choosing one dominant or preferred school of interpretation, the state is mandating what religious practices should be. This argument also raised the broader questions of whether a secular state has the authority to define religious mandates, and also whether this amounts to a violation of freedom of religion. ${ }^{20}$

One of the reasons articulated by India, Pakistan, Bangladesh and Kenya for the codification of Muslim Personal Laws is the protection of women from exploitation based on religious 
practices. Unfortunately, women are not protected from exploitation in the above-mentioned countries or in Nigeria, Malaysia, Sri Lanka and Tanzania. Violations of women's rights are common in executing provisions on divorce, polygynous marriages, custody of children and maintenance in all these countries. ${ }^{21}$ In some of these countries, courts have also succumbed to traditional definitions and customary practices and have overruled constitutional law provisions found in the fundamental rights section of the constitutions. A leading example is the Shah Bano case, which was decided in India during the 1980 's ${ }^{22}$. The case related to a divorce and maintenance [support] claim of an older woman who had no minor children. The Indian Supreme Court granted the woman maintenance and in its reasoning justified the decision under religious law, stating that its conclusion was in line with the Quranic ${ }^{23}$ spirit of $^{2}$ justice in respect of support for a person in need. Religious leaders objected to the decision and challenged the court's authority to interpret the Quran. Despite the progressive decision of the Supreme Court, the decision could not be enforced, because of extreme pressure from the religious leaders. As a consequence, a law was passed to effectively invalidate the court's decision and which "... deprived all and only Muslim women of the right of maintenance guaranteed under the Criminal Procedure Code." 24 One of the crucial issues that this case raises is that of the authority/power that codification processes grant to religious law implementers, even in a constitutional democracy that guarantees secularism and protection under a Bill of Rights. The lack of enforceability of a court judgment because of protests by religious leaders is an indicator of another difficulty with respect to achieving gender justice in plural legal systems.

There have also been cases in Malaysia and Nigeria that illustrate how the courts override constitutional law principles and disregard the bills of rights when interpreting religious law. Cases reveal how traditional definitions (including the definition of obedience) and interpretations of gender roles play a major role in deciding divorce, maintenance and custody issues. Some of the implications that have been common to the above mentioned countries in the process of codifying Muslim Personal Laws include: the violation of constitutional supremacy; violation of fundamental rights; affirmation of popular and customary views and beliefs on Islam such as 'polygamy is a man's right'; and challenges to the authority of the secular courts due to the existence of a parallel judicial system based on religious law. The SALRC bill replicates many provisions relating to Muslim Personal Laws that have been 
codified in these countries, and this could lead to similar problems. Amongst other provisions, the sections relating to maintenance and divorce indicate how the equality provisions of the constitution are being over-ridden by religious law provisions.

\section{4) South Africa's International Law Obligations}

This section will examine the United Nations system of international human rights law and the African regional systems of human rights law. From an international law perspective, there is strong support for individual and gender equality norms, and South African courts are expressly obliged to consider international law when interpreting the Bill of Rights. Section 39(1) of the Constitution states "... when interpreting the Bill of Rights, a court, tribunal or forum must promote the values that underlie an open and democratic society based on human dignity, equality and freedom ... and must consider international law." ${ }^{25}$ Amongst others, South Africa has ratified the International Covenant on Civil and Political Rights (ICCPR) in 1998; has signed (but not ratified) the International Covenant on Economic, Social and Cultural Rights (ICESCR) in 1994; has ratified the Convention on the Elimination of All forms of Discrimination Against Women (CEDAW) in 1995; and ratified the African Charter on Human and People's Rights (African Charter) in 1996. These documents all speak of the central place of equality norms in a democratic and pluralist society. Articles 18 and 26 of the ICCPR, in particular, promote both the individual's freedom of religion and the right to equality. Also, article 16 of CEDAW infuses this generalized language with muchappreciated specificity. It commands States Parties to “... ensure, on a basis of equality of men and women:

(a) The same right to enter into marriage;

(b) The same right freely to choose a spouse and to enter into marriage only with their free and full consent;

(c) The same rights and responsibilities during marriage and at its dissolution;

(d) The same rights and responsibilities as parents, irrespective of their marital status, in matters relating to their children; in all cases the interests of the children shall be paramount; 
(e) The same rights to decide freely and responsibly on the number and spacing of their children and to have access to the information, education and means to enable them to exercise these rights;

(f) The same rights and responsibilities with regard to guardianship, wardship, trusteeship and adoption of children, or similar institutions where these concepts exist in national legislation; in all cases the interests of the children shall be paramount;

(g) The same personal rights as husband and wife, including the right to choose a family name, a profession and an occupation;

(h) The same rights for both spouses in respect of the ownership, acquisition, management, administration, enjoyment and disposition of property, whether free of charge or for a valuable consideration." 26

The preamble of the African Charter on Human and Peoples' Rights sets out a duty for state members to achieve genuine equality and dignity for all people and dismantle all forms of discrimination. It honors both the universalist aspirations of the UN Charter and the Universal Declaration of Human Rights, and also the traditions and values of Africa which should “... inspire and characterize their reflection on the concept of human and peoples' rights. ${ }^{, 27}$ Relevant articles include:

(a)Article 2 entitles every individual to the enjoyment of the rights and freedoms in the Charter, without distinction of any kind such as race, ethnic group, color, sex, religion etc.

(b) Article 3 states that every individual shall be equal before the law and be entitled to equal protection of the law.

(c) Article 8 guarantees freedom of conscience, profession and free practice of religion.

(d) Article 17(2) and (3) states that "Every individual may freely take part in the cultural life of his [sic] community. The promotion and protection of morals and traditional values recognized by the community shall be the duty of the State" (emphasis added). ${ }^{28}$

(e) Article 18(3) requires states to eliminate "every discrimination against women" (emphasis added) and to protect women's rights "as stipulated in international declarations and conventions". In this way, the African Charter emphasizes women's rights by referring to pertinent international law, such as the ICCPR and CEDAW. 
(f) Article 19 states that "All peoples shall be equal; they shall enjoy the same respect and shall have the same rights. Nothing shall justify the domination of a people by another."

(g) Article 20 refers to the "unquestionable and inalienable right to self-determination." At first glance, the question that arises is whether the peoples referred to signify groups determined by nationality (e.g., South Africans) or race, ethnicity, culture, or religion (e.g., Muslims).

(h) Article 23, however, suggests that the former interpretation (i.e. national group) is closer to the truth when it says that "All peoples shall have the right to national and international peace and security." 29

South Africa is one of fifteen nations that have ratified the Maputo Protocol, formally called the Protocol to the African Charter on Human and Peoples' Rights on the Rights of Women in Africa. The Maputo Protocol, which was adopted by the African Union in July 2003 and came into force on 25 November 2005, speaks most directly to the issues at hand. The Protocol comprehensively enumerates the rights of women, imposing obligations on the ratifying states to ensure maximum protection of women's rights, prevent discrimination and undertake measures to ensure women are given appropriate space for development, equal opportunities and full protection of social, economic and civil rights. The preamble proclaims the rights of women to be "... inalienable, interdependent and indivisible human rights" and states its determination to enable women to “... enjoy fully all their human rights." strength of this language is significant in trying to create a hierarchy of rights. Specifically, it compels the state to take positive action of both a legislative and a social, cultural, educational nature. Relevant articles include:

a) Article 2 states that "... harmful cultural and traditional practices..." are those which “... are based on the idea of the inferiority or the superiority of either of the sexes, or on stereotyped roles for women and men."

b) The above provision is strengthened by Article 17, which states that women "...shall have the right to live in a positive cultural context and to participate at all levels in the determination of cultural policies." While there will certainly be disagreement over what constitutes a positive cultural context, the implication is that the cultural context is not and should not be static or fixed, and also that tradition is not inviolate if it is 
deemed not to be "positive" for women. The statement guaranteeing women the right to participate in the determination of cultural policies suggests that women should be, in large part, the ones deciding on what is positive for them. This suggests that tradition is not inviolate, and such change as is necessary to promote the free development of women's personalities is encouraged. ${ }^{31}$

c) Article 6 on marriage could scarcely be clearer in requiring states parties to "... ensure that women and men enjoy equal rights and are regarded as equal partners in marriage." Article 6(c) states that "... monogamy is encouraged as the preferred form of marriage and that the rights of women in marriage and family, including in polygamous marital relationship, are promoted and protected." The Protocol, while promoting monogamous marriages, recognizes the existence of polygamous marriages and the need for protection of the rights and interests of women in those marriages.

d) Article 7 ensures protection of women's rights by law, requiring that all marriages must be annulled or divorced by judicial order. Article 7 states that "States Parties shall enact appropriate legislation to ensure that women and men enjoy the same rights in case of separation, divorce or annulment of marriage." This entails that they shall (1) have the same rights to seek separation, divorce or annulment of a marriage; (2) have reciprocal rights and responsibilities towards their children; (3) have the right to an equitable sharing of the joint property deriving from the marriage. In short, these provisions are notable because they conflict with those found in both the SALRC and the CGE bills.

e) Article 8 requires reform of relevant discriminatory laws.

Thus, these various provisions in the Maputo Protocol demonstrate - some more clearly than others - an ultimate recognition that where the individual rights of women collide with the cultural or religious rights of a group, it is the former that must be given special protection. The African Court on Human Rights, a judicial mechanism of the African Charter on Human and People's Rights, is also empowered to apply the African Charter and also any other human rights treaty or convention ratified by the state parties. Thus provisions in both the Maputo Protocol and the African charter enable the both the domestic and the regional courts to draw on a broader pool of norms protecting human, and more particularly in this case, women's human rights. 


\section{5) Relevant Constitutional Provisions}

As stated previously, the South African Constitution should be interpreted in light of its historical context and its attempt to remedy the effects of both racial and gender discrimination. This remedial objective is embodied in its Preamble which states "...the people of South Africa recognize the injustices of our past ... adopt this Constitution as the supreme law of the Republic so as to: Heal the divisions of the past and establish a society based on democratic values, social justice and fundamental human rights [and] . . . Improve the quality of life of all citizens and free the potential of each person" (emphasis added). ${ }^{32}$ This purpose can also be seen in the main text of the Constitution, especially the Bill of Rights. Chapter 1, Section 1 sets out human dignity, equality, and non-sexism as foundational values. The constitutional guarantee of equality (s 9(1)) is the very first in the list of rights, and as such enjoys a special prominence. The Constitutional Court has often voiced this view, stating that "... the guarantee of equality lies at the very heart of the Constitution. It permeates and defines the very ethos upon which the Constitution is premised. ${ }^{, 33}$ Thus, in evaluating the proposed bills recognizing Muslim marriages, one should be keenly attuned to where they may heal some divisions and where they may instead create others. Moreover, one cannot rightfully ignore the problems of lingering patriarchal norms which sustain and idealize gender inequality and gender discrimination, either in theory or in practice, de jure or de facto.

Section 15 of the Bill of Rights provides that "Everyone has the right to freedom of conscience, religion, thought, belief and opinion," adding in section 15(3)(a) that this does not prevent legislation recognizing marriages or systems of personal or family law under any tradition or religion, so long as such recognition is consistent with this and other provisions of the Constitution (s15(3)(b)) (emphasis added). This condition is significant. First, it suggests that such legislation may conflict with other provisions of the Bill of Rights. Second, if it does, it clarifies that such legislation is subject to all other rights, including the equality right.

Section 31 creates a similar limitation. It mandates that "Persons belonging to a cultural, religious or linguistic community may not be denied the right, with other members of that community to (a) enjoy their culture, practice their religion and use their language." Despite 
this strong proclamation, the section goes on to state that these rights "... may not be exercised in a manner inconsistent with any provision of the Bill of Rights." ${ }^{34}$ In contrast, the equality clauses contain no such internal limitation, or 'but' clause.

The Promotion of Equality and Prevention of Unfair Discrimination $\mathrm{Act}^{35}$ is not simply relevant law, but also evidence of how the South African legislature interprets its own constitutional mandate. The guiding principle it stresses is the eradication of systemic racial and gender discrimination and inequality, which was injected into South African politics, economy, society, and psyche by an ill-famed triumvirate: colonialism, apartheid, and patriarchy. ${ }^{36}$ Chapter 2 , section 8 of the Act is devoted to clarifying the contours of gender discrimination. As such, it outlaws “... any practice, including traditional, customary or religious practice, which impairs the dignity of women and undermines equality between women and men."37

In adopting legislation to recognize Muslim marriages, balancing the rights of women and the rights of religious groups is at the heart of staying true to the Constitution and overcoming the history of discrimination. As indicated earlier, where these foundational rights collide, the equality of women must take precedence. The recognition of Muslim marriages on a par with all other religious marriages is not precluded. But cultural and religious rights, unlike equality rights, are subject to limitations described above, as well as the general limitations clause in section 36 of the Constitution. So, in determining the scope of the right to religion and the right to equality, it is the former which may not be read so as to infringe on the equality right, especially since non-sexism is one of the foundational values of the Republic of South Africa. Finally, as Wayne van der Meide has argued, "[A]lthough culture is practiced within and defined in reference to a group, in the Bill of Rights it is an individual, not a collective, right. Generally, therefore, the right to culture cannot be used to protect the interests of a group at the expense of the rights to equality, non-discrimination and inherent human dignity of individuals." 38

\section{6) Relevant Jurisprudence}

The right to equality has been widely explored by South Africa's courts. The Constitutional Court set out an equality test in Harksen v. Lane NO and Others, ${ }^{39}$ which mandated that any 
discrimination on the grounds of gender, race, ethnic origin, religion, disability and other grounds enumerated in the $\mathrm{s} 9$ of the constitution, is considered to be unconstitutional. The Court recognized both, past historical discrimination women faced in marriages in South Africa and also current experiences of women in relation to matrimonial property and the division of labor within the household, and how these factors compounded and further entrenched deep inequalities between women and men. While the test developed in the Harksen case certainly gives guidelines for determining absolute breaches of equality, it does not help to determine the balancing that must be done between gender and religious equality. In Bhe and Others $v$ the Magistrate, Khayelitsha and Others, ${ }^{40}$ the Constitutional Court resolved a conflict between African customary law and individual rights. In examining the rule of male primogeniture, which prohibited and discriminated against women's right to inherit property, the Court held that the customary law of succession, based largely on primogeniture, discriminates unfairly against women, both on the grounds of race and gender. This case supports the conclusion that when a conflict of rights arises, the right to gender equality takes precedence over cultural and religious rights.

South Africa's case law post-apartheid provides important direction on the legal treatment of Muslim marriages, the right to freedom of religion, and the right to gender equality. A few cases deal with the issue of Muslim marriages specifically and the right to marry generally. The pre-democracy era cases stand in sharp contrast to subsequent jurisprudence emanating from the courts. Under colonialism and apartheid, there was a refusal on the part of both the legislature and the courts to afford legal protection to parties in a Muslim marriage. The reason largely was that these marriages were viewed as potentially polygamous [polygynous] and thus contra bonos mores and hence were not regarded as legally valid. The views expressed in pre-democracy era cases were based on the dominant views on what religions and practices constituted civilized religious practices; what unions were considered an anathema to the dominant Christian norms; what marriages would not be reprobated by the majority of civilized peoples on grounds of morality and religion; what marriages were contrary to public policy etc. ${ }^{41}$ As we observe in the cases below, the courts have recognized the importance that religion has in this society, but have refused to use religious doctrine to interpret the constitution. 
Ryland v. Edros ${ }^{42}$ is a seminal example of the different approach to Muslim marriages adopted by the courts, when faced with an action for claims arising out of a marriage which was dissolved by Muslim Personal Laws. The Court asserted that the Constitution's values prohibited the imposition of a dominant community's preferences and prejudices (in this case prejudice against Muslim polygynous marriages) in a plural society like South Africa. ${ }^{43}$ At first glance, this might seem to support the argument that liberal/secular preferences for gender equality could not be imposed on the Muslim community. However, it is important to note that the Ryland decision was based on constitutional values, one of which is non-sexism. Thus, the Ryland case points towards the conclusion that the right to religious freedom emanates from the Constitution itself and, thus, religious freedom cannot be pursued without due regard to other central constitutional values, such as gender equality.

Amod v. Multilateral Motor Vehicle Accident Fund ${ }^{44}$ was a case related to compensation for the loss of support suffered as a consequence of the death of her husband in a car accident. The respondent had refused to pay compensation because Islamic marriages were not lawful at common law, since they were seen as contrary to good public policy, as they allowed for the practice of polygamy [polygyny]. ${ }^{45}$ The Court, in giving recognition to the duty of support owed to the appellant, recognized the existence of a de facto monogamous Muslim marriage.

In Daniels v. Campbell NO and others ${ }^{46}$ the Constitutional Court held that persons married according to Muslim rites were spouses for the purposes of inheritance where the deceased died without leaving a will. The court held further that the exclusion of people married under Muslim rites from the protection of the legislation in question is clearly an unjustifiably discriminatory remnant from the apartheid era. The common factor in the abovementioned cases was that in all instances the court was prepared to provide some remedy, but at the same time the court has consistently refused to recognize the legal status of marriages which are concluded under Muslim rites.

In addition, the recent Minister of Home Affairs and Another v. Fourie and Another ${ }^{47}$ decision on same-sex marriages asserted that the compass by which the 'right to marry' cases are decided should be South Africa's modern equality jurisprudence - which has focused on the values of human dignity, equality and freedom - rather than religious texts. ${ }^{48}$ The court 
declared, "[I] is one thing for the Court to acknowledge the important role that religion plays in our public life. It is quite another to use religious doctrine as a source for interpreting the Constitution. It would be out of order to employ the religious sentiments of some as a guide to the constitutional rights of others." 49 The Fourie case lends strong support to the contention that, in the marriage context, religious norms cannot outweigh the constitutionally-protected right to equality, and hence the inability of parties to lawfully marry their same sex partners constitutes discrimination. In summing up the jurisprudence, the Constitutional Court of South Africa has expanded the concept of marriage from a union of one man and one woman, to include same sex marriages; but it has also declined to recognize the legal validity of marriages conducted under the tenets of Muslim Laws.

The Constitutional Court has also faced another freedom of religion issue, i.e. whether giving special recognition to one religious group is unfair to other religious groups that lack such

special recognition. In $S v$. Solberg ${ }^{50}$, the majority held that state endorsement of a particular religion would not infringe on the right to freedom of religion, as long as the endorsement did not have a coercive effect. However, Justice O’Regan strongly dissented, and argued that any such endorsement would not be permitted in South Africa's new constitutional order. ${ }^{51}$

An important issue that Solberg raises in the Muslim marriages context is whether the SALRC draft bill creates 'coercive effects'. As will be outlined in the section below, one may well argue that the SALRC draft bill does this, insofar as it gives preferential treatment to some Islamic schools of interpretation over others and reinforces women's lesser socioeconomic status and autonomy, especially with regard to making religious and marital choices. There is additional case law on the legal treatment of the right to freedom of religion, but not specifically on the issue of Muslim marriages. Due to the constraints of space, such cases will not be discussed here.

\section{7) Some implications of the SALRC and CGE Approaches}

The SALRC draft bill (Muslim Marriages Act) and the CGE draft bill (Recognition of Religious Marriages Bill) take vastly different approaches to giving Muslim marriages legal status. Although several potential constitutional violations emerge from both proposed 
statutes, they will not all be addressed in this report. ${ }^{52}$ The views expressed by interviewees will be utilized in the discussion of a few provisions of both bills, including the scope of application; concerns arising due to codification of religious law; and, potential violation of women's equality rights. ${ }^{53}$ The report will address potential problems that focus on the provisions relating to divorce, matrimonial property regimes and maintenance.

\section{1) Scope of Application}

The SALRC bill applies only to Muslim marriages while the CGE bill applies to all religious marriages. The interviews reveal that some people are concerned that it is not fair to provide recognition of the tenets of one religious group and not to others. Other people argued that such recognition is patronizing to Muslims, as other religious groups are left to regulate themselves. ${ }^{54}$ The CGE bill may be seen to remedy this criticism as it seeks to recognize all religious marriages, rather than to codify specific elements of any religious laws. It thus becomes possible to address the problem of non-recognition of religious marriages and at the same time treat all religions equally within the context of a single act. Another challenge raised is the issue of legitimization of polygynous marriages through the SALRC Bill. Such legitimization is seen as infringing women's rights and is thus in direct violation of s9(2) of the Constitution. Both bills propose recognition of polygynous marriages, with the SALRC bill also providing for the regulation of polygamous marriages. Neither bill provides for the outlawing of the practice (even at some point in the future), thus ignoring the issues of substantive equality and the realization of the inherent human dignity of women, in religious communities. $^{55}$

\section{2) Some Implications of the Codification Approach}

It is important to firstly explore why the SALRC took the codification approach. The SALRC looked to the Constitution for legal support of codification of Muslim personal law. ${ }^{56}$ Section 15 of the Constitution opens the door by allowing for legislation recognizing systems of personal and family law under any tradition or adhered to by persons professing a particular religion - although any such legislation must be consistent with the rest of the Constitution. Also, the argument asserted in the SALRC Discussion Paper 101 was that Muslims currently had difficulty enforcing maintenance, termination of marriage, proprietary, and custody rights arising from their marriages and, thus, legislation must be specifically aimed at correcting 
these practical problems. The assertion was that women and children would be protected by specified substantive regulations. ${ }^{57}$ Of those interviewed, many people generally maintained that religious leaders had a strong influence over the SALRC Project Committee on the draft bill and that these leaders generally supported codification. One example cited, as common knowledge amongst many people in the Muslim community, was that the SALRC adopted the Muslim judge requirement in response to calls from religious (ulama) bodies. ${ }^{58}$

Thus, codification was asserted by the SALRC as a way to actively provide social protection in marital and family problems. The sections below will outline how the codification approach utilized in this bill has, in fact, accomplished the exact opposite of this goal, instead putting women and children at a greater disadvantage, both inter-groups and intra-groups. Many of these provisions are onerous in terms of a burden of proof; and they also presuppose access to knowledge and an equal power of parties to negotiate mutually favorable terms. The codification of religious laws approach focuses on protecting the religious group, with the emphasis being on formalizing group norms and institutions. In contrast, the recognition of religious marriages approach focuses on protecting the rights of the religious individual, with the emphasis being on personal choice of forum. Because individuals, especially women, are often subjugated even within protected minority groups, and because the individual is the lowest common denominator of both individual and group rights there is a greater imperative to protect individuals.

The SALRC bill seeks to codify elements of Muslim Personal Laws via the legislation itself and via the jurisprudence of Muslim judges and assessors. For example, it outlines rules for several marital situations relating to divorce practices such as talaq and khula ${ }^{59}$ and postdivorce practices such as $i d d a h .{ }^{60}$ In addition, this bill also prescribes that cases be tried by Muslim judges and assessors who have special knowledge of Islamic law. Many problems arise from this approach. At one level the concerns raised over codification of religious laws reflect a broader concern that the practices of many religious laws, including Muslim Personal Laws, are biased against women. The SALRC bill gives religious leaders greater discretion and authority, especially by mandating that Muslim judges and institutions play a central role in dispute resolution. This allows for the application of a variety of interpretations of religious laws, potentially in a biased manner. 
During interviews, some interviewees stated that the SALRC chose elements of Muslim Personal Laws in a piecemeal manner, picking and choosing from the four main schools of thought without regard to internal consistency or religious authenticity. Also, it was argued that by doing this, the state is attempting to legislate on the fundamentals of religious laws. This raises the broader question of whether the state has the authority to define religious mandates. Some also argued that the very act of crystallizing a specific set of religious rules in a piece of legislation goes against religious freedom and integrity, because religious tenets evolve and change over time and in different contexts. ${ }^{61}$ Many interviewees criticized the SALRC's process of consultation when drafting the bill, noting that women's voices were not adequately represented. ${ }^{62}$ Furthermore, the bill has raised dissent amongst Muslim scholars, with many holding that it violates freedom of religion by prescribing religious practices under coerciveness of state sanctions, and that it also infringes the autonomy of religious institutions. $^{63}$ It is argued that the Constitution of South Africa provides for the separation of state and religion and that this gives the government the power to provide religious groups the freedom to practice their religion. However, under the SALRC bill, the government exceeds this authority and prescribes what Islamic Law is, and, it also promotes a particular understanding of religion, thereby interpreting religious laws. As Motala holds “... the bill (SALRC) is not based on voluntarism. Instead, the state is attempting to prescribe how to worship or practice one's faith. The state should not be permitted to force or influence a person to profess a belief in a certain way." Further Motala suggests that there is a risk of alienating the Muslim communities in South Africa, because not all of them are in agreement with the prescriptions and interpretations provided for in the bill. ${ }^{64}$

Furthermore, in some interviews people expressed the belief that the SALRC's codification approach meant that many actions brought under the Act would eventually end up in the appeals process, on grounds of unconstitutionality, resulting in a cycle of appellate courts reversing the findings of Muslim judges. This is problematic as it allows non-Muslims to determine norms of Muslim Personal Laws, which is precisely what the SALRC bill sought to avoid by providing for the appointment of Muslim judges. Also, it sets up a dynamic of conflict between the secular state and the religious community, which again undermines one of the main objectives behind the proposed law. Furthermore, by creating a special role for Muslim judges and attorneys as judicial officers, the SALRC bill may convey existing 
distributional problems into the courtroom, thus contravening constitutional requirements. A history of gender discrimination likely restricts the number of female Muslim judges and attorneys. This issue is extremely relevant as recent judicial reform efforts have been focused on empowerment of women in the judiciary. ${ }^{65}$ The CGE bill does not provide for the appointment of Muslim judges. Finally, an even deeper problem is that, by formally codifying elements of religious laws, this bill would give any such underlying bias the weight of state sanction. It is this state approval that would bring applied religious law out of the private sphere and under the protection of state law, and not necessarily in a genderresponsive manner. Thus, the codification approach is problematic because it opens the door for the application of Muslim Personal Laws in a manner that potentially violates many constitutional provisions.

The CGE draft bill seeks only to recognize religious marriages and avoids issues of codification of specific religious tenets. This approach is preferable for several reasons. First, recognition rectifies the central problem of Muslim marriages lacking legal status. Second, the recognition approach balances the competing rights of gender equality and culture/religion, whereas the non-recognition and codification approaches allow one right to consume the other. That is, under the recognition model, a woman can either choose to have her dispute settled in the private religious sphere by a religious individual or institution, or she can use the fact that her marriage has legal status to trigger the mechanisms and laws of the secular legal arena. Therefore, the recognition model does not negate or disadvantage the application of Muslim Personal Laws; it simply gives people the option of utilizing either a religious or a secular forum. This approach seems eminently practicable since many interviewees indicated that many Muslim women already currently engage in such forum shopping, in the quest to resolve marital issues. ${ }^{66}$

It is important to note the limitations of the recognition of religious marriages approach. Because recognition leaves the private religious sphere unfettered, it leaves unfixed many of the underlying biases against women, on the part of religious leaders and institutions, just as codification goes too far in the other direction by lending state approval to these biased actors and institutions. This tension results in the conclusion that laws are not a panacea for dealing with violations of women's human rights arising out of religious practices and that other 
remedies must also be pursued. Another limitation is that the CGE bill effectively forces women to choose between an exclusive religious option and a secular option, whereas the SALRC bill seems to have some moderating effect through the appeals process. Also, in theory women have a choice of forum, but in practice this is not the case, as threats/coercion/fear etc may prevent them choosing the secular realm even if they wanted to.

\section{3) Potential Violations of Women's Equality Rights}

The SALRC bill provisions on divorce reveal a lack of clarity, disparate levels of power granted to male spouses (i.e. the entrenchment of legal inequality), and also a failure to pursue the substantive equality of women. For example, section 9(2) of the SALRC Bill provides that a court may terminate a Muslim marriage on any ground permitted by Islamic law. Yet, the bill fails to identify any of these grounds and thus opens the door to gender-biased interpretations of religious grounds. The CGE bill, on the other hand, simplifies and equalizes rights in divorce. It states that only a court may dissolve a marriage and the civil law standard of 'irretrievable breakdown' is sufficient ground for dissolution purposes. Unfortunately, the CGE bill also makes reference to ensuring that the marriage is dissolved according to religious tenets, prior to a court process of dissolution. The implications here include: having to deal with conservative religious institutions, bargaining in the shadow of the law with recalcitrant husbands, delayed processes etc. Also, the SALRC Bill, in codifying different forms of divorce and post-divorce practices, openly spells out and formalizes inequality in the law by giving the husband greater freedom to end the marriage. This is a violation of both domestic and international laws. One example is a provision on divorce which prohibits remarriage, for a mandatory waiting period of 130 days for a woman who is not pregnant and until the time of delivery for a woman who is pregnant (i.e. the iddah period). ${ }^{67}$

The process of dissolution of marriages under the SALRC Bill is another example of the different treatment in respect of divorce processes accorded to the Muslim community as compared to both civil law and customary law divorces. Under the SALRC bill, compulsory mediation is the first step in the process of dispute resolution. This can be followed by arbitration, and finally litigation if the matter is not resolved. Court proceedings will have to be presided over by a Muslim judge. Failing the existence of a Muslim judge in that Court, 
the matter will have to be heard by a Muslim attorney (who would be designated as an actingjudge). Courts would be assisted by two Muslim assessors who have specialized knowledge of Islamic Laws. On appeal, the Supreme Court of Appeal would submit questions of Islamic Law to two accredited Muslim institutions.

Numerous problems are evident in this approach. First, in court cases, the application of Islamic laws could introduce gender bias into both the procedure and substance of the case. Second, as noted earlier, by creating a special role for Muslim judges and attorneys as judicial officers, the SALRC bill may convey existing distributional problems into the courtroom. Third, because this bill mandates compulsory mediation, only Muslim people would be made to go through this additional procedural 'hoop' in order to gain access to the formal justice system. This puts Muslims at a disadvantage vis-à-vis non-Muslims with regard to their constitutionally protected right to have access to both due process and effective justice. Fourth, because arbitration is a private process, there is concern that gender bias will proceed unchecked by public scrutiny. Studies have found that private bargaining in family law tends to yield inferior results for many women. ${ }^{68}$ The CGE bill does not stipulate the appointment of religious judges, nor does it mandate compulsory mediation prior to adjudication processes for divorce. Hence, any underlying gender biases in the religious norms are further entrenched by the SALRC Bill, but neither are they fully confronted by the CGE Bill.

In the SALRC bill, the default position in respect of matrimonial property regimes for Muslim marriages is, as marriages out of community of property, excluding the accrual system. This is in contrast to the default system in both the civil law, i.e. the Marriage Act 25 of 1961 and also, the Recognition of Customary Marriages Act 120 of 1998, which provide for a default system of 'in community of property'. The SALRC bill provides that each spouse maintains his or her own estate and any growth accrued during the marriage will not be split between the two. This can be modified by a pre-nuptial contract, prior to the marriage ceremony. These provisions could serve to disadvantage women as male spouses can often more easily acquire hard assets during a marriage, while women may contribute more intangibly to family resources. Given the backdrop of existing gender inequality in terms of socio-economic resources, women are less able to assert their interests and demand an antenuptial contract. Also, under this bill, an application by the husband to enter into a 
subsequent marriage, may lead to the court dividing or terminating, an existing matrimonial property system. On the other hand, the CGE bill asserts that marriages will be governed by the tenets of the parties' religion. Although, this offers more room for the application of more equitable rules by the parties, by leaving the issues of proprietary consequences to the tenets of the religion, women in Muslim marriages are not protected from biased religious norms.

In terms of maintenance, the SALRC bill mandates that a husband supports his wife during marriage and for a limited period post-divorce (the iddah period) ${ }^{69}$, and that he pays child support to her upon divorce, but it has no provision for the payment of alimony. In contrast, the CGE bill would invoke the provisions of laws of general application that apply to marriage, divorce and maintenance. This is especially important since realistically in South Africa, many women traditionally labor in an unpaid or informal sector of the economy i.e. largely maintaining the household and caring for children. Furthermore, because of the historical legacy of a denial of education opportunities for non-white [black/people of color] people, women often lack the education and training required to later enter the work force if necessary. Hence, the lack of an equitable matrimonial system and a provision for alimony threatens to leave many women in financial jeopardy, if not utter destitution. As a result, this omission unfairly discriminates against women, both formally and substantively, de jure and de facto. The SALRC bill serves to further entrench inequality in South African law between Muslim and non-Muslim women.

\section{8) Conclusion}

It is acknowledged that law is only one part of any solution relating the achievement of women's human rights and substantive gender equality. Law is not a panacea for underlying social inequities, both structural and systemic. It will ultimately be up to South Africans to give life and meaning to the rights entrenched in the Bill of Rights. Article 2 of the Maputo Protocol exhorts governments to seek the elimination of discrimination against women not only through legislative measures, but also through the modification “ $\ldots$ of social and cultural patterns of conduct of women and men through public education, information, education and communication strategies, with a view to achieving the elimination of harmful cultural and 
traditional practices and all other practices which are based on the idea of the inferiority or the superiority of either of the sexes, or on stereotyped roles for women and men."70

There is a spectrum of opportunities to give status to Muslim marriages. On one end is the present state of non-recognition, which is harmful de facto to women and so flagrantly disregarding of the constitutional right to religion and culture of Muslim South Africans. On the opposite end is the SALRC bill. Its codification of Muslim Personal laws opens a Pandora's Box of constitutional quagmires that threatens to swallow whole the social justice mission embodied in the right to gender equality. In the middle stands the CGE bill, recognizing all religious marriages, but not codifying any religion. It partly represents the hope of a society in which the rights to equality and to culture, religion, and tradition may flourish side by side. The Constitution of South Africa is consciously an instrument committed to social justice, transformation and reconstruction. Thus any attempt to change, modify, challenge or violate the constitutional values and norms is required to be justified and must be judged in terms of the consequences and the impact it may induce. The constitutional provision under Chapter 2, article 7(2) holds a compelling obligation for the government indicating that it is required to undertake actions to ensure equal and fair implementation of rights. It gives rise to affirmative duties for the government to take proactive and affirmative steps to ensure that rights of individuals are not violated or infringed, not only by the state, but also by private parties.

Many country experiences demonstrate that codification of Muslim Personal Laws poses constitutional as well as religious law challenges. These challenges raise questions for states engaging in this process, to reconsider and revisit codification as the approach to recognition of religious laws. Such experiences also emphasize the highly delicate subject of accommodation in the family law arena, including essential problems underlying the current theoretical and legal models for dividing jurisdiction over individuals with multiple affiliations. In the South African multicultural context, the issue of recognition of Muslim marriages is of concern to its very plural fabric. Hence, its approach to multiculturalism is decisive to both its secularist and pluralist identity. The situation South Africa is faced with now demands a closer look at the different models of multiculturalism various countries have followed, and also the impact of their approaches in the recognition of Muslim Personal 
Laws. The South African context requires institutional scrutiny that can appreciate the situational complexity faced by individuals who are culturally and legally tied to both the group and the state. The challenge is balancing equality rights and the right to religion. From a social science perspective - from the perspective of life as it is lived as opposed to law as it is written - a codification bill, such as the SALRC bill, will be harmful to women even when it appears neutral, such as when it allows women to enter anti-nuptial contracts to change the matrimonial regime. The reality in South Africa is that women are generally of a lower socioeconomic status than men; hence it is highly unlikely that they will be able to truly use such provisions to protect their interests. Turning a blind eye to such realities promotes and perpetuates the social inequalities the Constitution was designed to address. The problem that has been identified is that of non-recognition of religious marriages. This is a problem that is faced by the Muslim community as well as other religious communities. The legislative solution that is required is one of recognizing religious marriages, while avoiding codifying any particular religion. 


\section{ENDNOTES}

${ }^{1}$ South African Law Reform Commission, Islamic Marriages and Related Matters: Report- Project 106 (July 2003).

${ }^{2}$ The Commission for Gender Equality (CGE) is a statutory body established in terms of the Constitution of South Africa and the Commission on Gender Equality Act No 39 of 1996. The mandate of the CGE is to promote respect for gender equality and the protection, development and attainment of gender equality. The powers and functions of the CGE are outlined in the Commission on Gender Equality Act 39 of 1996. In terms of section 11(1) (a) of this Act, the CGE, must, inter alia: Evaluate among others, any proposed law affecting gender equality or the status of women and make recommendations; and also evaluate any of the following: Acts of Parliament, systems of personal and/or family law, custom and/or customary practices, and systems of indigenous law or any other law.

${ }^{3}$ The Women's Legal Centre, South Africa is a public interest NGO that is planning to bring a class action application on behalf of its clients. Personal communication with Attorney J. Willams - 28 May 2007.

${ }^{4}$ See generally Jagwanth S, "The Inequality Challenge” 15 Southern Africa Report 3 (2000); and Karl Klare, "Legal Culture \& Transformative Constitutionalism," 14 South African Journal on Human Rights 146 (1998).

${ }^{5}$ Preamble, The Constitution of the Republic of South Africa, Act 108 of 1996.

${ }^{6}$ Brink v. Kitshoff 1996 (4) SA 197 (CC) at 33, 40.

${ }^{7}$ Ayelet Shachar, Multicultural Jurisdictions - Cultural Differences and Women's Rights (2001), Cambridge University Press. This section of the article is largely based on Pages 71-85.

${ }^{8}$ Id.

${ }^{9}$ Id. at 72

${ }^{10}$ Id. at 73

${ }^{11} \mathrm{Id}$.

${ }^{12}$ Id. at 72

${ }^{13}$ Id. at 77

${ }^{14} \mathrm{Id}$.

${ }^{15}$ Id. at 78

${ }^{16} \mathrm{Id}$.

${ }^{17}$ Id.

${ }^{18} \mathrm{Id}$

${ }^{19}$ Id. at 131

${ }^{20}$ Interviews conducted with various individuals in Oct 2005 in Cape Town, South Africa. In the interests of confidentiality, no names will be revealed. The list of interviewees is on file with the editor.

${ }^{21}$ See generally Women Living Muslim Laws Network website (www.wluml.org); particularly recent cases in Nigeria, Iran and Pakistan.

${ }^{22}$ Mohammad Ahmad Khan v. Shah Bano Begum, SCC 2 (1985) Sec. 556. In A.I.R.(The All India Reporter): July 1985, Vol 72 Part 859: pp.945-954. More details on the Shah Bano case can be found at http://www.law.emory.edu/IFL/cases/India.htm

${ }^{23}$ The Qur'an is regarded as the primary source of religious law and is considered by many Muslims to be the literal voice of God.

${ }^{24}$ Martha C. Nussbaum, "India: Implementing Sex Equality through Law" 2 Chicago .Journal of International Law (2001) at 45. See also the Muslim Women's Protection after Divorce Act (1986).

${ }^{25}$ The Constitution of the Republic of South Africa, Act 108 of 1996

${ }^{26}$ Convention on the Elimination of All Forms of Discrimination Against Women (CEDAW) adopted 18 Dec. 1979, G.A. Res. 34/180, U.N. Doc. A/34/46 (1980).

${ }^{27}$ African Charter on Human and Peoples' Rights adopted 27 June 1981 and came into force in 1986 OAU Doc. CAB/LEG/67/3 rev.5, 21 ILM (1982) 58. Also available: http:/www.Africa-Union.org/officialdocuments

${ }^{28}$ It is clear that the wording embraces the individual with free choice as the ultimate societal constituent. But it also raises questions about what interpretation should be attached to "community, morality and traditional values."

${ }^{29}$ See supra note 27

${ }^{30}$ Protocol to the African Charter on Human and Peoples' Rights on the Rights of Women in Africa (informally called the 'Maputo Protocol'. Available: http://www.Africa-Union.org/officialdocuments

${ }^{31}$ Article 2 seeks the elimination of discrimination against women not only through legislative measures, but also through the modification "of social and cultural patterns of conduct of women and men through public 
education, information, education and communication strategies, with a view to achieving the elimination of harmful cultural and traditional practices and all other practices which are based on the idea of the inferiority or the superiority of either of the sexes, or on stereotyped roles for women and men." This final statement makes it clear that it will be difficult to argue that inherent differences of the sexes justify their differing roles and spheres in life. Similarly, Article 3 on the right to dignity seeks to promote the free development of a woman's personality, though ultimately it is unclear how one might give content to these statements.

${ }^{32}$ Supra note 5

${ }^{33}$ Fraser v Children's Court, Pretoria North, \& others 1997 (2) 261 (CC) at para 20; See also, Minister of Home Affairs $v$ Fourie 2005 (CC) at para 59 (quoting Sv Makwanyane and Another 1995 (3) SA 391 (CC)).

${ }^{34}$ Section 31 (2) of Constitution. Supra note 25.

${ }^{35}$ Promotion of Equality and Prevention of Unfair Discrimination Act 4 of 2000.

${ }^{36}$ Id at Chapter 1, s4(2).

${ }^{37} \mathrm{Id}$ at Chapter 2, s8.

${ }^{38}$ Wayne van der Meide, “Gender Equality v Right to Culture”, 116 S. African L. J. 1051999.

${ }^{39}$ Harksen v. Lane NO 1997 (11) BCLR 1489 (CC).

${ }^{40}$ Bhe and Others v. Magistrate of Khayelitsha and others 2005 (1) BCLR 1 (CC).

${ }^{41}$ See generally Bronn v. Fritz Bronn's Executors and others 1860 (3) Searle 313; Seedat's Executors v. The Master 1917 A.D.; Kader v. Kader 1972 (3) SA 203 (A.D.); Ismail v. Ismail 1983 (1) SA 1006 (A.D.)

${ }^{42}$ Ryland v. Edros 1997 (1) BCLR 77 (C).

${ }^{43} I d$. at 460

${ }^{44}$ Amod v. Multilateral Motor Vehicle Accident Fund 1999 (4) SA 1319 (SCA).

${ }^{45}$ Du Plessis, Lourens, "Freedom of or Freedom from Religion?" 2001 B.Y.U. L. Rev. 439, at 461.

${ }^{46}$ Daniels v. Campbell NO and others 2004 (7) BCLR 735 (CC).

${ }^{47}$ Minister of Home Affairs and Another v. Fourie and Another CCT 60/04.

${ }^{48}$ Id at para 48

${ }^{49} I d$. at para 92

${ }^{50}$ S v. Solberg 1997 (10) BCLR 1348 (CC).

${ }^{51}$ As stated in Farlam, Paul. "The Ambit of the Right to Freedom of Religion: A Commentary on S v. Solberg", 1998 S.A.J.H.R (14) 298, at 301-302.

${ }^{52} \mathrm{~A}$ fuller analysis of the provisions in both Bills will be addressed in a forthcoming journal article.

${ }^{53}$ Supra note 20

${ }^{54} \mathrm{Id}$

${ }^{55}$ This criticism is also applicable to marriages recognized under the Recognition of Customary Marriages Act 120 of 1998

${ }^{56}$ Supra note 1 at $\mathrm{s} 1.2$

${ }^{57}$ South African Law Reform Commission, Islamic Marriages and Related Matters: Discussion Paper 101Project 59 (2001).

${ }^{58}$ Supra note 1 at s2.8.

${ }^{59}$ Talak, khula, faskh etc are different forms of divorce under Muslim personal laws. See SALRC Discussion Papers, supra note 58.

${ }^{60}$ Iddah is a mandatory 'waiting period' imposed on women on divorce or death of a spouse. Amongst others, the restrictions include not being able to marry and also not being able to leave the matrimonial home (with some exceptions allowed). The objective behind the 'waiting period' is to determine if the woman is pregnant. If so, the 'waiting period' extends to until she gives birth, as opposed to a waiting period of three months on divorce and just over four months on death.

${ }^{61}$ Supra note 20.

${ }^{62}$ Id.

${ }^{63}$ See generally Moosa E, "Prospects for Muslim Law in South Africa: A History and Recent Developments" in Yearbook of Islamic and Middle Eastern Law, Volume 3 1996; "What is MPL?" published by: Young Men's Muslim Association (South Africa), undated; Al-Haq Bulletin No. 21, Oct 2003 (Published in Port Elizabeth, South Africa)

${ }^{64}$ Motala Z, "The Draft Bill on the Recognition of Muslim Marriages: An Unwise, Improvident and Questionable Constitutional Exercise" Undated. Found on website: http://www.alinaam.org.za/misc/mplc01.htm Accessed 6/7/2006

${ }^{65}$ Angela Quintal, "SA's Judges to go back to school: racism, sexism problems for judiciary, says report." Weekend Post, 22 October, 2005.

${ }^{66} I d$. 
${ }^{67}$ Supra note 61

${ }^{68}$ Bakht Natasha, Family Arbitration Using Sharia Law: Examining Ontario's Arbitration Act and its Impact on Women. 1 Muslim World Journal of Human Rights 1. 2004.

${ }^{69}$ Supra note 61

${ }^{70}$ Supra note 30. 